\title{
Potent Antioxidative Activity of Lycopene: A Potential Role in Scavenging Hypochlorous Acid †
}

\author{
Subramaniam Pennathurף,1, Dhiman Maitra ${ }^{\ddagger}, 1$, Jaeman Byunף, Inga Sliskovic $\ddagger$, Ibrahim \\ Abdulhamid $\|$, Ghassan M. Saed ${ }^{\ddagger}$, Michael P. Diamond ${ }^{\ddagger}$, and Husam M. Abu-Soud $\S^{\ddagger},^{*}$ \\ FDepartments of Obstetrics and Gynecology, The C.S. Mott Center for Human Growth and \\ Development \\ $\S$ Departments of Biochemistry and Molecular Biology, The C.S. Mott Center for Human Growth \\ and Development
}

"Department of Pediatrics, Children's Hospital of Michigan, Wayne State University School of Medicine, Detroit, Michigan 48201

"Division of Nephrology, Department of Internal Medicine, University of Michigan, Ann Arbor, Michigan 48109

\begin{abstract}
Lycopene, a carotenoid found in tomatoes, is a proven anti-oxidant that may lower the risk of certain disorders including heart disease and cancer. Hypochlorous acid $(\mathrm{HOCl})$ is an oxidant linked to tissue oxidation in cardiovascular disease and other inflammatory disorders through its ability to modify proteins, deoxyribonucleic acid, ribonucleic acid and lipids. Here we show that lycopene can function as a potent scavenger of $\mathrm{HOCl}$ at a wide range of concentrations that span various pathophysiological and supplemental ranges. The oxidation of lycopene by $\mathrm{HOCl}$ was accompanied by a marked change in color, from red to colorless, of the lycopene solution suggesting lycopene degradation. HPLC and LC-MS analysis showed that the exposure of lycopene to increasing concentrations of $\mathrm{HOCl}$ gave a range of metabolites resulting from oxidative cleavage of one or more $\mathrm{C}=\mathrm{C}$. The degree of degradation of lycopene (as assessed by the number and chain lengths of the different oxidative metabolites of lycopene) depends mainly on the ratio between $\mathrm{HOCl}$ to lycopene, suggesting that multiple molecules of $\mathrm{HOCl}$ are consumed per molecule of lycopene. Collectively, this work demonstrates a direct link between lycopene and $\mathrm{HOCl}$ scavenging, and may assist in elucidating the mechanism of the protective function exerted by lycopene.
\end{abstract}

\footnotetext{
$\dagger$ This work was supported by a grant from the National Institutes of Health (RO1 HL066367, H.M.A-S.), and a grant from Children’s Hospital of Michigan (H.M.A-S). SP is a recipient of a Clinical Scientist Development Award from the Doris Duke Foundation. The authors thank Professor Peter R. Andreana (Wayne State University; Chem Dept) for mechanistic insights.

(C) 2010 Elsevier Inc. All rights reserved.

*Corresponding Author: Husam Abu-Soud, Ph.D, Department of Obstetrics and Gynecology, Wayne State University School of Medicine, The C.S. Mott Center for Human Growth and Development, 275 E. Hancock Detroit, MI 48201, Tel. 313 577-6178, Fax. 313 577-8554, habusoud@med.wayne.edu.

${ }^{1}$ The authors contributed equally to this work.

Publisher's Disclaimer: This is a PDF file of an unedited manuscript that has been accepted for publication. As a service to our customers we are providing this early version of the manuscript. The manuscript will undergo copyediting, typesetting, and review of the resulting proof before it is published in its final citable form. Please note that during the production process errors may be discovered which could affect the content, and all legal disclaimers that apply to the journal pertain.
} 


\section{Keywords}

Lycopene; myeloperoxidase; hypochlorous acid; carotenoid oxidation

\section{Introduction}

Lycopene, the red pigment of tomato, is a tetraterpene assembled from eight isoprene units, composed entirely of carbon and hydrogen containing 11 conjugated and 2 non-conjugated carbon-carbon double bonds $(\mathrm{C}=\mathrm{C})$ (Figure 1). It is one of the most interesting unsaturated carotenoids with well-known health benefits [1,2]. Lycopene concentration in human serum tends to be higher than all other carotenoids pigments [2]. Increasing evidence suggests that lycopene could be involved in protection against chronic disorders such as cardiovascular disease, prostate cancer, respiratory and digestive epithelial cancers [3-7]. Lycopene exerts potent anti inflammatory effects through its action as an antioxidant and free radical scavenger, which may reduce cellular damage [8,9]. It also plays an important role in protecting cell membranes from lipid peroxidation, neutralizing hydroxyl radicals and may bind to DNA, promoting further protection beyond antioxidant activity. Additionally, lycopene may stimulate antioxidative enzymes such as superoxide dismutase, glutathione peroxidase, and glutathione reductase [10], as well as inhibit $\mathrm{H}_{2} \mathrm{O}_{2}$-induced lipid peroxidation and lipoprotein modification [11]. The mechanism by which lycopene exerts these antioxidant properties in vivo has not yet been elucidated.

Lycopene metabolites generated through lycopene oxidation may have different activities than lycopene or can display completely new and independent biological functions [12]. Indeed, studies from several laboratories have demonstrated potential beneficial effects of lycopene specifically in response to oxidants. These beneficial functions include enhanced cellular gap junction communication, induction of phase II enzymes through activation of the antioxidant response element (ARE) transcription system, suppression of insulin-like growth factor-1-stimulated cell proliferation by induction of insulin-like growth factor binding protein, anti-angiogenesis, inhibition of cell proliferation, and induction of apoptosis $[12,13]$.

$\mathrm{HOCl}$ and its conjugate base $\left(\mathrm{OCl}^{-}\right)$are potent oxidants that function as powerful antimicrobial agents. [14]. However, the properties of $\mathrm{HOCl}$ that makes it such a potent antimicrobial agent may also endanger the host, as it can damage the host tissue by the same mechanism used to destroy invading pathogens [15]. HOCl is generated enzymatically by myeloperoxidase (MPO), a neutrophil derived heme peroxidase, which uses hydrogen peroxide $\left(\mathrm{H}_{2} \mathrm{O}_{2}\right)$ produced during respiratory burst to catalyze the two electron oxidation of chloride $\left(\mathrm{Cl}^{-}\right)$. $\mathrm{HOCl}$ is implicated as a contributing factor in a number of pathological conditions including inflammatory diseases, atherosclerosis, respiratory distress, acute vasculitis, rheumatoid arthritis, glomerulonephritis and cancer [16-20]. Recently, we showed that $\mathrm{HOCl}$ plays an important role in accelerating oocyte aging through a mechanism that involves oocyte fragmentation and degradation [21]. Different types of biological molecules react with $\mathrm{HOCl}$. For example, NADH and NH-groups of pyrimidines nucleotides are chlorinated by a $\mathrm{HOCl}$-induced reaction. $\mathrm{HOCl}$ causes extensive denaturation of double-stranded DNA [22, 23]. $\mathrm{HOCl}$ can convert tyrosine residues in a protein to form 3-chlorotyrosine [24]. In lipids the major site of attack by $\mathrm{HOCl}$ are the double bonds of unsaturated fatty acids and cholesterol, leading to either chlorohydrin formation [24] or peroxidation [25, 26]. In addition to being a potent oxidant itself, $\mathrm{HOCl}$ can react with other compounds to produce other reactive oxidant species (ROS) and free radicals. For example, $\mathrm{HOCl}$ can react with superoxide $\left(\mathrm{O}_{2}{ }^{--}\right)$to generate hydroxyl radical $\left({ }^{\circ} \mathrm{OH}\right)[27,28]$. In alkaline solution hypochlorite, the conjugate base of $\mathrm{HOCl}$ reacts with 
$\mathrm{H}_{2} \mathrm{O}_{2}$ to yield singlet oxygen species [29]. Importantly, these ROS and free radicals subsequently generated from $\mathrm{HOCl}$ may cause further cellular damage.

MPO and its downstream final products have recently been used as markers for many chronic disorders. Consequently, inhibition of MPO and/or eliminating its end product, $\mathrm{HOCl}$, is a topic of great interest in several laboratories. More recently, we have shown that melatonin, tryptophan, and tryptophan analogues display the potential capacity to reversibly inhibit MPO through the accumulation of MPO Compound II (MPO-Fe(IV)=O), an inactive MPO intermediate [30-32]. The aim of this work is to highlight the potential role of lycopene as a pathway of $\mathrm{HOCl}$ scavenging, to identify the $\mathrm{HOCl}$-mediated oxidative products of lycopene, and their cleavage mechanism. Identification of potent scavenger of $\mathrm{HOCl}$ from dietary supplements may provide novel avenues for preventing initiation, progression and development of inflammation-related pathological states.

\section{Materials and Methods}

\section{Materials}

All the materials used were of highest purity grade and used without further purification. Lycopene was obtained from Toronto Research Chemicals Inc. (ON, Canada). Sodium hypochlorite $(\mathrm{NaOCl})$, tetrahydrofuran (THF), ammonium acetate $\left(\mathrm{CH}_{3} \mathrm{COONH}_{3}\right)$, taurine, and 5, 5-Dithiobis (2-nitro-benzoic acid) were obtained from Sigma Aldrich (St. Louis, MO, USA). HPLC grade methanol, acetonitrile $\left(\mathrm{CH}_{3} \mathrm{CN}\right)$, isopropanol and chloroform were obtained from Acros (Belgium).

\section{Spectral analysis}

Optical spectra were recorded on a Cary 100-Bio UV-visible spectrophotometer at $23^{\circ} \mathrm{C}$. Lycopene was prepared as $4 \mathrm{mM}$ stock solution dissolved in chloroform and stored at -80 ${ }^{\circ} \mathrm{C}$ until further use. Care was taken not to expose lycopene solution to light, either during stock solution preparation or experimentation. To measure the effect of $\mathrm{HOCl}$ on lycopene destruction, $12.5 \mu \mathrm{l}$ aliquots of the lycopene stock solution were removed and diluted to 500 $\mu \mathrm{CHCl}_{3}$ in Pyrex test-tubes, and the lycopene solutions then received equal volume of aqueous solution $(500 \mu 1)$ containing increasing concentration of $\mathrm{HOCl}(0-3750 \mu \mathrm{M})$. The solution mixtures were vortexed continuously for $2 \mathrm{~min}$ in the dark and the aqueous layer was removed. $50 \mu \mathrm{l}$ from the organic phase was diluted to $1 \mathrm{ml}$ in $\mathrm{CHCl}_{3}$ and the absorbance spectra were scanned form 200 to $700 \mathrm{~nm}$.

\section{High Performance Liquid Chromatography (HPLC) analysis}

HPLC analyses was carried out using a Shimadzu HPLC system equipped with a SCL-10A system controller, with a binary pump solvent delivery (LC-10 AD) module and a SIL-10AD auto-injector connected to a SPD-M10A diode array detector (DAD). Alltech 5 $\mu \mathrm{m}$ particle size, $4.6 \times 150 \mathrm{~mm}$ reverse-phase octadecylsilica (C18) HPLC column was used. The column was kept at $27^{\circ} \mathrm{C}$. The photodiode array detector was set at $450 \mathrm{~nm}$ to obtain the chromatogram. The gradient system used was a slight modification of a previously published method [33]. After oxidation with $\mathrm{HOCl}$, the chloroform layer was evaporated under a stream of nitrogen and then the dried sample was re-suspended in the injection solvent $\left(25 \mu 1 \mathrm{CHCl}_{3}\right.$ and $\left.975 \mu 1 \mathrm{CH}_{3} \mathrm{CN}\right)$ solution, and $50 \mu 1$ were injected. The column was eluted at a flow rate of $1.0 \mathrm{~mL} / \mathrm{min}$ with linear gradients of solvents $\mathrm{A}$ and $\mathrm{B}$ (A, $\mathrm{CH}_{3} \mathrm{CN}$ : THF: $1 \% \mathrm{CH}_{3} \mathrm{COONH}_{3}$ in $\mathrm{H}_{2} \mathrm{O}=50: 20: 30$, v/v/v; B, $\mathrm{CH}_{3} \mathrm{CN}$ : THF: $1 \%$ $\mathrm{CH}_{3} \mathrm{COONH}_{3}$ in $\left.\mathrm{H}_{2} \mathrm{O}=50: 44: 6, \mathrm{v} / \mathrm{v} / \mathrm{v}\right)$. The solvent gradient used were, A-70 \%, B-30\% at start, then a linear gradient increase of $\mathrm{B}$ to $70 \%$ in $70 \mathrm{~min}$, then a steeper gradient to increase B to $100 \%$ in $1 \mathrm{~min}$ and hold at $100 \% \mathrm{~B}$ for $10 \mathrm{~min}$. At the end of the run the system was equilibrated with $100 \%$ solvent A. Under these conditions, lycopene eluted at 
around 46 min and was detected from the characteristic spectral signal from the Diode Array Detector. Each sample was analyzed in triplicate.

\section{Mass spectrometric analysis}

Mass spectrometry (MS) experiments were performed using an Agilent 6410 Triple Quadrapole mass spectrometer coupled with an Agilent 1200 HPLC system (Agilent Technologies, New Castle, DE), equipped with a multimode source. Alltech Prevail C18 column (particle size $5 \mu \mathrm{m} ; 4.6 \times 150 \mathrm{~mm}$; Nicholasville, $\mathrm{KY}$ ) was used to separate reaction products. Solvent A was methanol and solvent B was isopropanol. The column was equilibrated with $80 \%$ solvent A and $20 \%$ solvent B. The gradient was: $20-50 \%$ solvent B over $12 \mathrm{~min}$; $50 \%$ solvent B for $2 \mathrm{~min}$; 50-20\% solvent B for $1 \mathrm{~min}$; and $80 \%$ solvent A for $15 \min .2 \mu \mathrm{L}$ of the reaction mixture was injected at a flow rate of $1 \mathrm{~mL} / \mathrm{min}$. Liquid chromatography atmospheric pressure chemical ionization (LC/APCI) MS in the positive and negative modes were performed using the following parameters: spray voltage $2500 \mathrm{~V}$, drying gas flow $5 \mathrm{~L} / \mathrm{min}$, drying gas temperature $350^{\circ} \mathrm{C}$, vaporizer temperature $150^{\circ} \mathrm{C}$, and nebulizer pressure $20 \mathrm{psi}$. Flow injection analysis (FIA) was used to optimize the fragmentor voltage. Optimal fragmentor voltage for lycopene was $130 \mathrm{~V}$ in MS2 scan mode. Mass range between $\mathrm{m} / \mathrm{z} 100$ and $\mathrm{m} / \mathrm{z} 700$ was scanned to obtain full scan mass spectra.

\section{Solution preparation}

HOCl preparation- $\mathrm{HOCl}$ was prepared following a slight modification of a published method [34]. Briefly, a stock solution of $\mathrm{HOCl}$ was prepared by adding $7.5 \mathrm{ml} \mathrm{NaOCl}$ solution to $10 \mathrm{ml}$ potassium phosphate $\left(\mathrm{KH}_{2} \mathrm{PO}_{4}\right)$ solution $(100 \mathrm{mM})$. The concentration of $\mathrm{HOCl}$ in this stock solution was determined by the taurine chloramine assay [35]. As $\mathrm{HOCl}$ is unstable, the stock solution was freshly prepared on a daily basis, stored on ice, and used within one hour of preparation. For further experimentations, dilutions were made from the stock solution using $100 \mathrm{mM} \mathrm{KH}_{2} \mathrm{PO}_{4}$, to give working solutions of lower $\mathrm{HOCl}$ concentration.

\section{Results $\mathrm{HOCl}$-promotes lycopene oxidation}

Lycopene, a member of the carotenoid pigment family, possesses a characteristic red color. Lycopene, like all carotenoids, has the ability to absorb light in the 400-500 nm region of the visible spectrum. We initially studied the reaction of $\mathrm{HOCl}$ with lycopene to understand the role of lycopene in $\mathrm{HOCl}$ scavenging, and to isolate and identify lycopene cleavage products. Reactions were carried out at $25^{\circ} \mathrm{C}$ in chloroformic solution. From our initial experiments we observed the disappearance of lycopene color to determine whether $\mathrm{HOCl}$ promotes its oxidation. The oxidation of lycopene by a slight excess of $\mathrm{HOCl}$ was accompanied by a marked change from red color to colorless (Fig. 2, inset). The color disappeared rapidly, and after 2 min a complete loss of the red color of lycopene occurred. Fig. 2 compares the absorbance spectra of lycopene exposed to increasing concentration of $\mathrm{HOCl}$ with that of untreated lycopene. The visible spectrum of lycopene displayed characteristic peak centered at 460, 486, and $520 \mathrm{~nm}$ in chloroform. Exposure of a fixed amount of lycopene to increasing concentration of $\mathrm{HOCl}$ caused lycopene exhaustion, as indicated by the flattening, shift, and disappearance of its characteristic absorbance peaks. Lycopene is an unsaturated hydrocarbon with $13 \mathrm{C}=\mathrm{C}$, of which 11 double bonds are conjugated and the characteristic UV-visible spectra of lycopene is due to this hyperconjugated double bonds in the molecule (Fig. 1). The disappearance of lycopene spectra could be due to the loss of hyperconjugation in the molecule and/or lycopene fragmentation. 


\section{HPLC analysis of lycopene oxidation products}

As $\mathrm{HOCl}$ is thought to oxidize carotenoids, we examined if these spectral transformations that is apparent from our UV-visible spectral analysis may represent the oxidation and subsequent fragmentation of lycopene by HOCl. HPLC analysis was performed (as mentioned in the materials and methods section), to study the reaction products after oxidation of lycopene with $\mathrm{HOCl}$. We incubated a fixed amount of lycopene $(50 \mu \mathrm{M})$ with increasing $\mathrm{HOCl}$ concentrations $(250,500,625 \mu \mathrm{M})$. When lycopene was reacted with $\mathrm{HOCl}$ there was a progressive reduction in the lycopene signal (as a function of $\mathrm{HOCl}$ concentration) along with the formation of new peaks eluting at earlier time, Fig. 3A shows the chromatograms for control and the different reaction mixtures at $450 \mathrm{~nm}$. In our method lycopene eluted at $47 \mathrm{~min}$ and was identified by its characteristic spectra observed from the photodiode array detector. Calculating the area under the curve for lycopene revealed that in a sample treated with $250 \mu \mathrm{M}$ of $\mathrm{HOCl} 12 \%$ of lycopene was remaining; while in $500 \mu \mathrm{M}$ of $\mathrm{HOCl} 0.5 \%$ of lycopene was remaining. Complete loss of the lycopene peak was observed in $625 \mu \mathrm{M}$ of $\mathrm{HOCl}$ (Fig. 3B). The fact that there is residual lycopene remaining at $500 \mu \mathrm{M}$ of $\mathrm{HOCl}$ proves that one molecule of lycopene is capable of scavenging multiple molecules of HOCl. The appearance of newer earlier eluting peaks in the chromatograms, could be due to the formation of new compounds with shorter chain lengths and subsequently lower hydrophobicity.

\section{LC/APCI/MS analysis of lycopene oxidation products}

LC/APCI/MS was utilized to elucidate whether HOCl-mediated reaction products of lycopene, were indeed due to oxidation and fragmentation of the lycopene molecule. To optimize the MS parameters 100 pmol of lycopene was first analyzed by flow injection analysis (FIA) method at different fragmentor voltages in APCI positive and negative ionization modes. Optimal fragmentor voltage for lycopene was determined to be $130 \mathrm{~V}$ in MS2 scan mode. Several solvent systems were evaluated to obtain maximal ion intensity of MS detector. Ammonium acetate and tetrahydrofuran suppressed ion intensity. Therefore, we chose isopropanol because this solvent has the same polarity with tetrahydrofuran and does not significantly suppress ionization. Methanol and iospropanol gradient as described in Methods gave the best ion intensity (data not shown).

The predominant species of lycopene metabolite in the chloroformic solution with lycopene: $\mathrm{HOCl}$ of 1:5 was eluted at $2.86 \mathrm{~min}$, and identified as $\mathrm{m} / \mathrm{z} 393$ in the APCI positive mode. The extracted ion chromatogram for $\mathrm{m} / \mathrm{z} 393$ and the mass spectrum of this compound is depicted in Fig. 4A and 4B respectively. The second major peak was observed at $1.75 \mathrm{~min}$ and identified as $\mathrm{m} / \mathrm{z} 349$. This compound contains 2 carbonyl groups and represents double oxidative modifications (Fig 5 and Table 1). Incubation of lycopene with 1:10 and 1:12.5 ratios gave a range of metabolites. In the sample with a ratio of 1:10 (lycopene to $\mathrm{HOCl}$ ) a series of long chain compounds were obtained with $\mathrm{m} / \mathrm{z}$ values of $301,393,413,437,441$, 469 and 475 and elution times of 2.05, 2.86, 2.69, 1.85, 2.96, 3.18 and 1.78 min, respectively. In contrast, after the incubation of lycopene with higher concentration of $\mathrm{HOCl} /{ }^{-} \mathrm{OCl}(1: 15$ and 1:20) all lycopene was consumed, and traces of $\mathrm{m} / \mathrm{z} 301$ was still detectable. In addition, the chloroformic solution with a ratio of 1:15 showed the formation of two new metabolites with elution times of 2.26 and $2.38 \mathrm{~min}$ with $\mathrm{m} / \mathrm{z}$ values of 329 and 421 , respectively, while the solution of a ratio of 1:20 led to the generation of three new metabolites: a) $\mathrm{m} / \mathrm{z} 443$; elution time $1.86 \mathrm{~min}$; b) $\mathrm{m} / \mathrm{z} 443$; elution time $2.14 \mathrm{~min}$; and c) $\mathrm{m} /$ $Z 449$; elution time $2.03 \mathrm{~min}$. The extracted ion chromatogram of $\mathrm{m} / Z 443$ is depicted in Fig 6 A showing the 2 elution times for this mass indicating presence of two distinct compounds. Examination of the mass spectrum (Fig 6B) of the first compound reveals presence of one chlorine atom as the ion intensity of $[\mathrm{M}+\mathrm{H}+2]^{+}$ion is approximately $40 \%$ of $[\mathrm{M}+\mathrm{H}]^{+}$ indicating a chlorine isotope pattern. In contrast, the isotopic pattern of $\mathrm{m} / \mathrm{z} 443$ from the 
second peak has no intense $[\mathrm{M}+\mathrm{H}+2]^{+}$ion (Figure 6C) indicating that this product is not chlorinated. In the negative ion mode, peaks were observed for $\mathrm{m} / \mathrm{z}$ values of $255,281,283$, 409,437 and 473 with elution times of $2.12,2.07,2.40,2.50,2.80$, and $4.12 \mathrm{~min}$ respectively.

The majority of the products were tentatively identified by detecting the corresponding molecular weight and comparing the proposed structures with the previously identified products, and/or due to the chemical reactivity of $\mathrm{HOCl}$ with carotenoids [36]. Identification of the eluted reaction products identified the presence of three type of lycopene oxidation. The first group contains lycopene metabolites resulting from single oxidative cleavage. These metabolites contain on one end an acid and/or an aldehyde group, and on the other end of the metabolite the $\Psi$-end group of lycopene, and are called apo-lycopenal and apolycopenoic acid. In the positive APCI mode, the $\mathrm{m} / \mathrm{z} 393$ (Figure 4) and $\mathrm{m} / \mathrm{z} 443$ (Fig 6C) are likely produced by single oxidative cleavage.

The second group contains lycopene metabolites resulting from a double oxidative cleavage. This category of lycopene metabolites contain two acid end groups and are called apocarotendials, because their structure could have been obtained from any carotenoid and not only from lycopene. The $\mathrm{m} / \mathrm{z} 349$ (Fig. 5) represents such a compound.

The third group contains other compounds resulting from further chlorination of group 2 and is called chloro-apo-carotendial. The $\mathrm{m} / \mathrm{z} 443$ (Fig $6 \mathrm{~B}$; retention time $1.86 \mathrm{~min}$ ) represents a chlorinated lycopene metabolite.

\section{Discussion}

Increased levels of $\mathrm{HOCl}$, a potent oxidant, are typically observed in the plasma and tissues of individuals with inflammatory diseases [37]. And yet, a functional deficiency of taurine, a potent $\mathrm{HOCl}$ scavenger, is a defining feature of diabetes, obesity, depression, hypertension, gout, kidney failure, and autism, among other conditions [38, 39]. Previous epidemiological evidence has suggested that the intake of lycopene is associated with a reduced risk for many chronic disorders including prostate cancer and heart diseases [40]. Although most investigators have attributed the potential protective role of lycopene in the prevention of chronic diseases to its antioxidant function [41], the exact mechanism by which lycopene exerts these antioxidant effects have not been fully elucidated. Using a combination of direct UV-visible, HPLC and LC/APCI/MS, we have shown that increasing concentration of $\mathrm{HOCl}$ can alter the availability of lycopene through a mechanism that involves lycopene oxidation and fragmentation. Exposure of lycopene to saturated amounts of $\mathrm{HOCl}$ caused a distinct bleaching in color suggesting lycopene destruction. HPLC and LC-MS analysis showed that exposure of lycopene to increasing concentrations of $\mathrm{HOCl}$ gave a range of metabolites resulting from the oxidative cleavage of one or more $\mathrm{C}=\mathrm{C}$. $\mathrm{HOCl}$ may directly mediate the destruction of lycopene by unselective cleavage at any double bond position in a nonenzymatic manner. HOCl-mediated lycopene oxidation was rapid in chloroformic solution, and a total of thirteen different cleavage products have been identified based on their mass signals through the treatment of lycopene solution with a range of $\mathrm{HOCl}$ ( $1: 5$ to 1:20 molar ratio). The degree of degradation of lycopene (as assessed by the number and chain lengths of the different oxidative metabolites of lycopene) depends mainly on the ratio between $\mathrm{HOCl}$ to lycopene, suggesting that multiple molecules of $\mathrm{HOCl}$ are consumed per molecule of lycopene. Thus, $\mathrm{HOCl}$ interaction with lycopene may serve as a potential mechanism for modulating its availability, and thereby influencing the regulation of local inflammatory and infectious events in vivo. 
These cleavage products can be classified into three major categories according to the degree of oxidation and their cleavage position within the lycopene molecule: the first group contains lycopene metabolites resulting from single oxidative cleavage. These metabolites contain on one end an aldehyde/or an acid group and on the other end of the metabolite the $\Psi$-end group of lycopene, and were called apo-lycopenal and apo-lycopenoic acid. Indeed, two apo-lycopenal and two apo-lycopenoic acids were obtained and tentatively identified based on the $m / Z$ value. Apo-lycopenal isolated fragments showed that the double bonds 5-6 (or $5^{\prime}-6^{\prime}$ ), was affected, whereas apo-lycopenoic acid showed that the double bonds 13-14 (or $13^{\prime}-14^{\prime}$ ), $15-15^{\prime}$ and $9-10$ (or $9^{\prime}-10^{\prime}$ ) were affected by the cleavage. All the apolycopenoic acid fragments (acycloretioic acid, apo-14'-lycopenoic acid, and apo-10' lycopenoic acid) were identified at both low (1:5) and high (1:20) lycopene to $\mathrm{HOCl}$ ratio. Apo-lycopenal fragments (apo-6'-lycopenal) were identified at only higher lycopene to $\mathrm{HOCl}$ ratio (Table 1). The second group resulting from the oxidation and modification of the both end groups of lycopene that could occur at position 1-2 (or $1^{\prime}-2^{\prime}$ ) or at any other position to produce lycopene metabolites with: two acids, two aldehydes, or combination of both acid and aldehyde on the two end groups and was called apo-carotendials, because their structure could have been obtained from any carotenoid and not only from lycopene. In case of apocarotendials where the $1-2$ (or $1^{\prime}-2^{\prime}$ ) in one side and the other side showed that the double bonds (7-8) (or $\left.7^{\prime}-8^{\prime}\right)$ were affected whereas the corresponding acids showed that the double bonds $7-8$ (or $7^{\prime}-8^{\prime}$ ), 11-12 (or $11^{\prime}-12^{\prime}$ ) and 5-6 (or $5^{\prime}-16^{\prime}$ ) were affected by the cleavage. In addition, among the different products isolated, three fragments were oxidatively modified at both ends of lycopene's hyperconjugated chain. These three products were crocetin semialdehyde, crocetin, and apo- $5^{\prime}, 6^{\prime}$ carotendial (Table 1). The third group contains other compounds resulting from further chlorination of lycopene metabolites, called chloro-apo-carotendials. This includes $\mathrm{m} / \mathrm{z} 443$ which is a chlorinated lycopene fragment: 2 hydroxy 3 chloro 4,6,8,10,12,14,16,18 docosoctene 1,22 diol $6,11,15,19$ tetramethyl. Thus, taken together; the results in our studies suggest that the HOCl-mediated cleavage reaction of lycopene and the degree of oxidation could occur unselectively at any position of the lycopene double bonds independent of $\mathrm{HOCl}$ concentration. The formation of long-chains was not detected in higher ratio of lycopene to $\mathrm{HOCl}$ (e.g., 1:30, data not shown), suggested that the detected fragments are further oxidized to shorter-chain lengths upon increasing the $\mathrm{HOCl}$ concentration.

In the case of potassium permanganate-mediated generation of apo-carotendials, CarisVeyrat et al. have shown that only the double bonds $5-6$ (or $\left.5^{\prime}-6^{\prime}\right), 7-8$ (or $7^{\prime}-8^{\prime}$ ), 9-10 (or $9^{\prime}-10^{\prime}$ ), and $11-12$ (or $11^{\prime}-12^{\prime}$ ) were affected by the cleavage. But they did not detect apo-carotendials/ones resulting from cleavages of double bonds closer to the center of the molecule $\left(15-15^{\prime} \mathrm{C}=\mathrm{C}\right)$ [44]. No cleavage was detected on the double bond which is the farthest from the center of the molecule, i.e., the 1-2 double bond, which is not conjugated and is trisubstituted. The author attributed this behavior to the non-reactivity of these positions to the oxidation with potassium permanganate [44]. No products resulting from a double oxidative cleavage (apo-carotendial) were detected upon exposure of lycopene to the oxidative catalytic species trans-dioxoruthenium( VI)-tetraphenylporphyrin $\mathrm{Ru}(\mathrm{O})_{2}(\mathrm{TPP})$ over a period of $96 \mathrm{~h}$ [44]. Instead ( $Z$ )-isomers, compounds with a molecular weight of $\mathrm{m} / \mathrm{Z}$ $553=\left[M_{\text {lycopene }}+16+\mathrm{H}\right]^{+}$, which we called lycopene monoxides, and cleavage compounds assigned to apo-lycopenals [44]. Almost all the apo-lycopenals/ones that were obtained by oxidation of lycopene with potassium permanganate were detected, except the short-chain apo-5-lycopenone and apo-7-lycopenal (44). Thus, our results may suggest that $\mathrm{HOCl}$ behaves as a stronger oxidant with a higher oxidation potential than permanganate and other oxidants for lycopene destruction.

Many of the metabolites in groups 1and 2 have been reported as their metabolic pathways were investigated extensively while other cleavage products and their functions are either 
not yet fully explained or not mentioned before in the literature. For example, earlier in vitro studies by Ben-Aziz et al. have shown that apo- $6^{\prime}$ - and apo- $8^{\prime}$ - lycopene were obtained by oxidation of lycopene with potassium permanganate [42]. Cross-sequential studies by Ukai et al. described a protocol for the reaction which gave apo- $6^{\prime}$-lycopenal as the main product after 44 hours, whereas $50 \%$ of lycopene remained intact [43]. Caris-Veyrat et al. have latter optimized the experimental conditions by modifying the solvent mixture and the phase transfer catalyst to complete oxidized lycopene and obtained mono oxidative cleavage compounds as major products [44]. After the complete disappearance of lycopene, they detected eight apo-lycopenals giving a range of products from the longest apo- 6 '-lycopenal to the shortest one detected apo-5-lycopenone, three apo-lycopenones, and six apocarotendials [45]. Using HPLC analysis with UV-visible detection Kim et al. have tentatively identified mono cleavage compounds of lycopene [46]. Exposure of lycopene to atmospheric oxygen and perfusion of ozone has led to tentatively identify a (E, E, E)-4methyl-8-oxo-2,4,6-nonatrienal [45]. Kim et al. isolated and identified a cleavage product of lycopene from an autoxidation mixture of lycopene products [46].

Previous studies have also shown that lycopene undergoes oxidative degradation in vivo [46]. Some of the lycopene cleavage products identified in this work (Table 1) have been shown to participate in biological effects in animal models and cell culture system. Indeed, several of lycopene metabolites have been found in human milk and serum [47]. Consistent with our current finding, these studies have concluded that lycopene can unselectively been cleaved at any double bond position in nonenzymatic manner when organisms are subjected to oxidative stress $(33,44,45,48)$. Since several of the HOCl-mediated lycopene cleavage products of different chain lengths assigned in group 1 and 2 (Table I) have been identified and shown to be associated with reduced risk of certain cancers [49-52], we believe that our work could be biologically relevant. Indeed, it has been thought that lycopene metabolites may induce changes in the gene level attaining the expression of relevant genes and serve as anticancer agents [53]. Related studies by Nara et al. have shown that a mixture of oxidation products of lycopene induced apoptosis in HL-60 cells following incubation for $24 \mathrm{~h}$, at $37^{\circ} \mathrm{C}$ [54]. Kotake-Nara et al. have shown that acyclo-retinoic acid, the centrally cleaved metabolite of lycopene, reduces cell viability by inducing apoptosis in human prostate cancer cells [55]. Aust et al., have show that 2,7,11-trimethyl-tetradecahexaene-1,14-dial, generated by lycopene degradation, products in cell signaling enhancing cell-to-cell communication through gap junctions in rat liver epithelial WB-F344 cells [56]. In addition, apo-10'-lycopenoic acid was also found to be a lycopene metabolite in ferret lung tissue [57]. In parallel, several other lycopene metabolites with different functional groups have previously been reported, for example, 5,6-dihydroxy-5',6'-dihydrolycopene and 2,6cyclolycopene-1,5-diol A and B have been found in the extracts of human serum/plasma $[47,58]$.

Identifying similarities and differences in the interactions between $\mathrm{HOCl}$ and various oxidants yields valuable mechanistic insights into the potential biochemical and functional significance of HOCl-lycopene interactions both in vitro and in vivo. On the basis of the present results, previous published studies of the interaction of $\mathrm{HOCl}$ with carotenoids, and the exposure of lycopene to different oxidants (e.g., permanganates and metalloporphyrins), we have generated a stepwise scheme that shows possible pathways for the generation of different lycopene cleavage products after the exposure to increasing concentration of $\mathrm{HOCl}$ (Fig. 7). In this reaction, lycopene interacts with the $\mathrm{HOCl}$ molecule in which the chloride atom of $\mathrm{HOCl}$ acts as an electrophile and the electron rich olefin initially acts as the nucleophile. When the $\mathrm{Cl}$ atom adds across the double bond, it does so in such a mannar in which a pseudo-secondary carbo-cation is formed transforming to a more stable chloronium ion. Addition of the hydroxide proceeds by obeying the regioselectivity of nucleophilic chloronium ion ring opening. The semi-halohydrin then undergoes an epoxide ring forming 
reaction via an intramolecular $\mathrm{S}_{\mathrm{N}} 2$ type in which a chlorine atom is displaced. Reaction of the epoxide with a second molecule of $\mathrm{HOCl}$ (deprotonated by $\mathrm{Cl}^{-}$) causes cleavage of the terminal carbon-carbon bond and the generation of an aldehyde (which is one carbon shorter than the parent epoxide from which it was formed). Further oxidation of the aldehyde by a third molecule of $\mathrm{HOCl}$ leads to the formation of carboxylic acid. Thus, it is evident that one molecule of lycopene (which has thirteen $\mathrm{C}=\mathrm{C}$ ) has the potential capacity to scavenge multiple molecules of $\mathrm{HOCl}$.

The degree of reproducibility and similarity of the isolates increased progressively when the LC/MS analyses were carried out immediately after the extraction of the cleavage products in chloroformic solutions and subsequently as dry powders. The delay of $20-45 \mathrm{~h}$ in LC/MS analysis caused a noticeable decrease in the chlorinated compounds (group 3 ), indicating that the chlorinated molecules are relatively unstable and may decay to non-chlorinated species such as aldehydes and carboxylic acids. The metabolites in groups 3 and their metabolic pathways have not been previously reported. The excessive $\mathrm{HOCl}$ generated under inflammatory conditions when phagocytes are activated and MPO is released may play a harmful role due to its ability to react eagerly with a variety of biological molecules, and its ability to chlorinate as well as oxidize biomoleules [59]. Indeed, there is substantial evidence that MPO and $\mathrm{HOCl}$ play a role in atherosclerosis, diabetes and asthma, and $\mathrm{HOCl}$-mediated tissue injury has also been found to result in an increase in inflammatory disorders as determined by increased levels of free and protein-bound chlorotyrosine and achloro fatty aldehydes [reviewed in 60 and 61].

The generation of a series of chlorohydrins of cholesterol[6- $\beta$-chloro-cholestane-( $3 \beta, 5 a)$ diol, 5 - $\alpha$-chloro-cholestane-( $3 \beta, 6 \beta)$-diol and 6 - $\alpha$-chloro-cholestane-( $3 \beta, 5 \beta)$-diol has been observed following exposure to $\mathrm{HOCl}$, as well as dichlorinated product, 5,6-dichlorocholestane-3 $\beta$-ol $[62,63]$. In addition to electrophilic addition, $\mathrm{HOCl}$ can utilize $\mathrm{N}$ halogenation reactions at amines in the head groups of phosphatidylethanolamines and phosphatidylserines, yielding corresponding chloramines [64,65]. These intermediate products are initial short lived molecules, and tend to decay to a more stable non-chlorinated species such as aldehydes. $\mathrm{HOCl}$ reacts very rapidly with the sulfur-containing side chains of methionine and cysteine residues and, at a slightly lower rate constant, with amines and other nitrogen-containing residue $[66,67]$. The ability of lycopene to scavenge $\mathrm{HOCl}$ formed during inflammatory situations is more likely to prevent proteins and unsaturated phospholipids from MPO- and HOCl-induced damage. Thus reduced lycopene availability and/or increased consumption as assessed by the degree of its fragmentation and modification may reflect the basic mechanism of increasing the risk of diseases induced by $\mathrm{MPO}$ and $\mathrm{HOCl}$.

In summary, inhibition of MPO or removing its downstream final product, $\mathrm{HOCl}$, is an attractive target for preventing $\mathrm{HOCl}$-mediated tissue injury and progression of inflammatory diseases. In this study we advance the current knowledge of lycopene antioxidant properties and show for the first time that lycopene may serve as a potent scavenger of $\mathrm{HOCl}$. The interplay between lycopene and $\mathrm{HOCl}$ may have a broad implication in the function of inflammatory biological systems throughout the body. Further evaluation is necessary to assess whether lycopene could represent an interventional approach to minimize the deleterious effects associated with inflammation.

\section{The abbreviations used are:}
ARE
antioxidant response element
$\mathrm{Cl}^{-}$
chloride 


$\begin{array}{ll}\text { DNA } & \text { deoxyribonucleic acid } \\ \text { FIA } & \text { flow injection analysis } \\ \mathbf{H}_{2} \mathrm{O}_{2} & \text { hydrogen peroxide } \\ \text { HOCl } & \text { hypochlorous acid } \\ \text { HPLC } & \text { High Performance Liquid Chromatography } \\ \text { LC/APCI/MS } & \text { Liquid chromatography/atmospheric pressure chemical ionization/mass } \\ & \text { spectrometry } \\ \text { m/z } & \text { mass to charge ratio } \\ \text { MPO } & \text { Myeloperoxidase } \\ \text { RNA } & \text { ribonucleic acid } \\ \text { ROS } & \text { reactive oxidant species } \\ \text { DNA } & \text { deoxyribonucleic acid }\end{array}$

\section{References}

1. Agarwal S, Rao AV. Tomato lycopene and its role in human health and chronic diseases. Can. Med. Assoc. J. 2000; 163:739-744. [PubMed: 11022591]

2. Khachik F, Carvalho L, Bernstein PS, Muir GJ, Zhao DY, Katz NB. Chemistry, distribution, and metabolism of tomato carotenoids and their impact on human health. Exp. Biol. Med. 2002; 227:845-851.

3. Matos HR, Di Mascio P, Medeiros MH. Protective effect of lycopene on lipid peroxidation and oxidative DNA damage in cell culture. Arch Biochem Biophys. 2000; 383:56-59. [PubMed: 11097176]

4. Voutilainen S, Nurmi T, Mursu J, Rissanen TH. Carotenoids and cardiovascular health. Am J Clin Nutr. 2006; 83:1265-1271. [PubMed: 16762935]

5. Dahan K, Fennal M, Kumar NB. Lycopene in the prevention of prostate cancer. J Soc Integr Oncol. 2008; 6:29-36. [PubMed: 18302908]

6. Rao AV. Lycopene, tomatoes, and the prevention of coronary heart disease. Exp Biol Med (Maywood). 2002; 227:908-913. [PubMed: 12424333]

7. Heber D. Colorful cancer prevention: alpha-carotene, lycopene, and lung cancer. Am J Clin Nutr. 2000; 72:901-902. [PubMed: 11010928]

8. Zhao YP, Yu WL, Hu WL, Ying Y. Anti-inflammatory and anticoagulant activities of lycopene in mice. Nutrition Research. 2003; 23:1591-1595.

9. Saedisomeolia A, Wood LG, Garg ML, Gibson PG, Wark PA. Lycopene enrichment of cultured airway epithelial cells decreases the inflammation induced by rhinovirus infection and lipopolysaccharide. J Nutr Biochem. 2009; 20:577-585. [PubMed: 18824341]

10. Subhash K, Bose C, Agrawal BK. Effect of short term supplementation of tomatoes on antioxidant enzymes and lipid peroxidation type-II diabetes. Indian Journal of Clinical Biochemistry. 2007; 22:95-98. [PubMed: 23105660]

11. Tang X, Yang X, Peng Y, Lin J. Protective effects of lycopene against $\mathrm{H}_{2} \mathrm{O}_{2}$-induced oxidative injury and apoptosis in human endothelial cells. Cardiovasc Drugs Ther. 2009 (ahead of print).

12. Mein JR, Lian F, Wang X-D. Biological activity of lycopene metabolites: implications for cancer prevention. Nutrition Reviews. 2008; 66:667-683. [PubMed: 19019036]

13. Zhang LX, Cooney RV, Bertramm JS. Carotenoids enhance gap junctional communication and inhibit lipid peroxidation in $\mathrm{C} 3 \mathrm{H} / 10 \mathrm{~T} 1 / 2$ cells: relationship to their cancer chemopreventive action. Carcinogenesis. 1991; 12:2109-2114. [PubMed: 1934296] 
14. Klebanoff, SJ. Oxygen Metabolites from Phagocytes. In: Gallin, JI.; Snyderman, R., editors. Inflammation: Basic Principles and Clinical Correlates. Philadelphia: Lippincott Williams \& Wilkins; 1999. p. 721-768.

15. Pullar JM, Vissers MC, Winterbourn CC. Living with a killer: the effects of hypochlorous acid on mammalian cells. IUBMB Life. 2000; 50:259-266. [PubMed: 11327319]

16. Malech HL, Gallin JI. Neutrophils in human diseases. N. Engl. J. Med. 1987; 317:687-694. [PubMed: 3041216]

17. Malle E, Buch T, Grone HJ. Myeloperoxidase in kidney disease. Kidney Int. 2003; 64:956-967.

18. Ohshima H, Tatemichi M, Sawa T. Chemical basis of inflammation-induced carcinogenesis. Arch Biochem Biophys. 2003; 417:3-11. [PubMed: 12921773]

19. Schiller J, Fuchs B, Arnhold J, Arnold K. Contribution of reactive oxygen species to cartilage degradation in rheumatic diseases: molecular pathways, diagnosis and potential therapeutic strategies. Curr Med Chem. 2003; 20:2123-2145. [PubMed: 12871089]

20. Hazen SL, Heinecke JW. 3-Chlorotyrosine, a specific marker of myeloperoxidasecatalyzed oxidation, is markedly elevated in low density lipoprotein isolated from human atherosclerotic intima. J. Clin. Invest. 1997; 99:2075-2081. [PubMed: 9151778]

21. Goud AP, Goud PT, Diamond MP, Gonik B, Abu-Soud HM. Reactive oxygen species and oocyte aging: role of superoxide, hydrogen peroxide, and hypochlorous acid. Free Radic Biol Med. 2008; 44:1295-1304. [PubMed: 18177745]

22. Prutz WA. Hypochlorous acid interactions with thiols, nucleotides, DNA, and other biological substrates. Arch Biochem Biophys. 1996; 332:110-120. [PubMed: 8806715]

23. Prutz WA. Interactions of hypochlorous acid with pyrimidine nucleotides, and secondary reactions of chlorinated pyrimidines with GSH, NADH, and other substrates. Arch Biochem Biophys. 1998; 349:183-191. [PubMed: 9439597]

24. Bergt C, Pennathur S, Fu X, Byun J, O'Brien K, McDonald TO, Singh P, Anantharamaiah GM, Chait A, Brunzell J, Geary RL, Oram JF, Heinecke JW. The myeloperoxidase product hypochlorous acid oxidizes HDL in the human artery wall and impairs ABCA1-dependent cholesterol transport. Proc Natl Acad Sci U S A. 2004; 101(35):13032-13037. [PubMed: 15326314]

25. Winterbourn CC, van den Berg JJ, Roitman E, Kuypers FA. Chlorohydrin formation from unsaturated fatty acids reacted with hypochlorous acid. Arch. Biochem. Biophys. 1992; 296:547555. [PubMed: 1321589]

26. Zhang R, Brennan ML, Shen Z, MacPherson JC, Schmitt D, Molenda CE, Hazen SL. Myeloperoxidase functions as a major enzymatic catalyst for initiation of lipid peroxidation at sites of inflammation. J Biol Chem. 2002; 277:46116-46122. [PubMed: 12359714]

27. Candeias LP, Patel KB, Stratford MRL, Wardman P. Free hydroxyl radicals are formed on reaction between the neutrophil-derived species superoxide anion and hypochlorous acid. FEBS Lett. 1993; 333:151-153. [PubMed: 8224156]

28. Long CA, Bielski BHJ. Rate of reaction of superoxide radical with chloride-containing species. J. Phys. Chem. 1980; 84:555-557.

29. Held AM, Halko DJ, Hurst JK. Mechanisms of chlorine oxidation of hydrogen peroxide. J. Am. Chem. Soc. 1978; 100:5732-5740.

30. Galijasevic S, Abdulhamid I, Abu-Soud HM. Melatonin is a potent inhibitor for myeloperoxidase. Biochemistry. 2008; 47:2668-2677. [PubMed: 18237195]

31. Galijasevic S, Abdulhamid I, Abu-Soud HM. Potential role of tryptophan and chloride in the inhibition of human myeloperoxidase. Free Radic Biol Med. 2008; 44:1570-1577. [PubMed: 18279680]

32. Sliskovic I, Abdulhamid I, Sharma M, Abu-Soud HM. Analysis of the mechanism by which tryptophan analogs inhibit human myeloperoxidase. Free Radic Biol Med. 2009; 47:1005-1013. [PubMed: 19596067]

33. dos Anjos Ferreira AL, Yeum KJ, Russell RM, Krinsky NI, Tang G. Enzymatic and oxidative metabolites of lycopene. J Nutr Biochem. 2004; 15:493-502. [PubMed: 15378815] 
34. Sutherland WH, de Jong SA, Walker RJ. Hypochlorous acid and low serum paraoxonase activity in haemodialysis patients: an in vitro study. Nephrol Dial Transplant. 2004; 19:75-82. [PubMed: 14671042]

35. Kettle AJ, Winterbourn CC. Assays for the chlorination activity of myeloperoxidase. Methods Enzymol. 1994; 233:502-512. [PubMed: 8015486]

36. Sommerburg O, Langhans CD, Arnhold J, Leichsenring M, Salerno C, Crifò C, Hoffmann GF, Debatin KM, Siems WG. Beta-carotene cleavage products after oxidation mediated by hypochlorous acid--a model for neutrophil-derived degradation. Free Radic Biol Med. 2003; 35:1480-1490. [PubMed: 14642396]

37. Pattison DI, Hawkins CL, Davies MJ. What are the plasma targets of the oxidant hypochlorous acid? A kinetic modeling approach. Chem Res Toxicol. 2009; 22:807-817. [PubMed: 19326902]

38. Schaffer SW, Azuma J, Mozaffari M. Role of antioxidant activity of taurine in diabetes. Can J Physiol Pharmacol. 2009; 87:91-99. [PubMed: 19234572]

39. Bouckenooghe T, Remacle C, Reusens B. Is taurine a functional nutrient? Curr Opin Clin Metab Care. 2006; 9:728-733.

40. Giovannucci E. Tomatoes, tomato-based products, lycopene, and cancer: review of the epidemiologic literature. J Nalt Cancer Inst. 1999; 91:317-331.

41. Arab L, Steck S. Lycopene and cardiovascular disease. Am J Clin Nutr. 2000; 71:1691S-1695S. [PubMed: 10837319]

42. Ben-Aziz A, Britton G, Goodwin TW. Carotene Epoxides of Lycopersicon escculentum. Phytochemistry. 1973; 12:2759-2764.

43. Ukai N, Lu Y, Etoh H, Tagi A, Ina K, Oshima S, Ojima F, Sakamoto H, Ishiguro Y. Photosensitized oxygenation of lycopene. Biosci. Biotech. Biochem. 1994; 58:1718-1719.

44. Caris-Veyrat C, Schmid A, Carail M, Bohm V. Cleavage products of lycopene produced by in vitro oxidations: characterization and mechanisms of formation. J Agric Food Chem. 2003; 51:7318-7325. [PubMed: 14640578]

45. Zhang H, Kotake-Nara E, Ono H, Nagao A. A novel cleavage product formed by autoxidation of lycopene induces apoptosis in HL-60 cells. Free Radic Biol Med. 2003; 35:1653-1663. [PubMed: 14680688]

46. Kim S-J, Nara E, Kobayashi H, Terao J, Nagao A. Formation of cleavage products by autoxidation of Lycopene. Lipids. 2001; 36:191-199. [PubMed: 11269700]

47. Khachik F, Spangler CJ, Smith JC Jr, Canfield LM, Steck A, Plander H. Identification, quantification, and relative concentrations of carotenoids and their metabolites in human milk and serum. Anal Chem. 1997; 69:1873-1881. [PubMed: 9164160]

48. Gajic M, Zaripheh S, Sun F, Erdman JW Jr. Apo-8'-Lycopenal and Apo-12'-Lycopenal Are Metabolic Products of Lycopene in Rat Liver. J Nutr. 2006; 136:1552-1557. [PubMed: 16702320]

49. Hu X, White KM, Jacobsen. NE, Mangelsdorf DJ, Canfield LM. Inhibition of Growth and Cholesterol Synthesis in Breast Cancer Cells by Oxidation Products of $\beta$-Carotene. J. Nutr. Biochem. 1998; 9:567-574.

50. Giovannucci E, Ascherio A, Rimn EB, Stampfer MJ, Colditz GA, Willett WC. Intake of Carotenoids and Retinol in Relation to Risk of Prostate Cancer. J. Natl. Cancer Inst. 1995; 87:1767-1776. [PubMed: 7473833]

51. Gann PH, Ma J, Giovannucci E, Willett W, Sacks FM, Hennekens CH, Stampfer MJ. Lower Prostate Cancer Risk in Men with Elevated Plasma Lycopene Levels:Results of a Prospective Analysis. Cancer Res. 1999; 59:1225-1230. [PubMed: 10096552]

52. Chen G, Djuric Z. Detection of 2,6-cyclolycopene-1,5-diol in breast nipple aspirate fluids and plasma: a potential marker of oxidative stress. Cancer Epidemiol Biomarkers Prev. 2002; 11:1592-1596. [PubMed: 12496049]

53. Freemantle SJ, Spinella MJ, Dmitrovsky E. Retinoids in cancer therapy and chemoprevention: promise meets resistance. Oncogene. 2003; 22:7305-7315. [PubMed: 14576840]

54. Nara E, Hayashi H, Kotake M, Miyashita K, Nagao A. Acyclic carotenoids and their oxidation mixtures inhibit the growth of HL-60 human promyelocytic leukemia cells. Nutr Cancer. 2001; 39:273-283. [PubMed: 11759292] 
55. Kotake-Nara E, Kim SJ, Kobori M, Miyashita K, Nagao A. Acyclo-retinoic acid induces apoptosis in human prostate cancer cells. Anticancer Res. 2002; 22:689-695. [PubMed: 12014638]

56. Aust O, Ale-Agha N, Zhang L, Wollersen H, Sies H, Stahl W. Lycopene oxidation product enhances gap junctional communication. Food Chem. Toxicol. 2003; 41:1399-1407. [PubMed: 12909274]

57. Lian F, Smith DE, Ernst H, Russell RM, Wang X-D. Apo-10'-lycopenoic acid inhibits lung cancer cell growth in vitro, and suppresses lung tumorigenesis in the $\mathrm{A} / \mathrm{J}$ mouse model in vivo. Carcinogenesis. 2007; 28:1567-1574. [PubMed: 17420169]

58. Khachik F, Beecher GR, Smith JC Jr. Lutein, lycopene, and their oxidative metabolites in chemoprevention of cancer. J Cell Biochem Suppl. 1995; 22:236-246. [PubMed: 8538204]

59. Henderson JP, Byun J, Heinecke JW. Molecular chlorine generated by the myeloperoxidasehydrogen peroxide-chloride system of phagocytes produces 5-chlorocytosine in bacterial RNA. J Biol Chem. 1999; 274:33440-33448. [PubMed: 10559226]

60. Nicholls SJ, Hazen SL. Myeloperoxidase, modified lipoproteins, and atherogenesis. J Lipid Res. 2009; 50(Suppl):S346-S351. [PubMed: 19091698]

61. Vivekanandan-Giri A, Wang JH, Byun J, Pennathur S. Mass spectrometric quantification of amino acid oxidation products identifies oxidative mechanisms of diabetic end-organ damage. Reviews in Endocrine and Metabolic Disorders. 2008; 9:275-287. [PubMed: 18752069]

62. Hazen SL, Hsu FF, Duffin K, Heinecke JW. Molecular chlorine generated by the myeloperoxidase-hydrogen peroxide-chloride system of phagocytes converts low density lipoprotein cholesterol into a family of chlorinated sterols. J. Biol. Chem. 1996; 271:23080-23088. [PubMed: 8798498]

63. Carr AC, van den Berg JJ, Winterbourn CC. Chlorination of cholesterol in cell membranes by hypochlorous acid. Arch. Biochem. Biophys. 1996; 332:63-69. [PubMed: 8806710]

64. Pattison DI, Hawkins CL, Davies MJ. Hypochlorous acid-mediated oxidation of lipid components and antioxidants present in low-density lipoproteins: absolute rate constants, product analysis, and computational modeling. Chem. Res. Toxicol. 2003; 16:439-449. [PubMed: 12703960]

65. Kawai Y, Kiyokawa H, Kimura Y, Kato Y, Tsuchiya K, Terao J. Hypochlorous acid-derived modification of phospholipids: characterization of aminophospholipids as regulatory molecules for lipid peroxidation. Biochemistry. 2006; 45:14201-14211. [PubMed: 17115715]

66. Pattison DI, Davies MJ. Reactions of myeloperoxidase derived oxidants with biological substrates: gaining chemical insight into human inflammatory diseases. Curr. Med. Chem. 2006; 13:32713290. [PubMed: 17168851]

67. Pitt AR, Spickett CM. Mass spectrometric analysis of HOCl- and free-radical-induced damage to lipids and proteins. Biochem Soc Trans. 2008; 36:1077-1082. [PubMed: 18793192] 


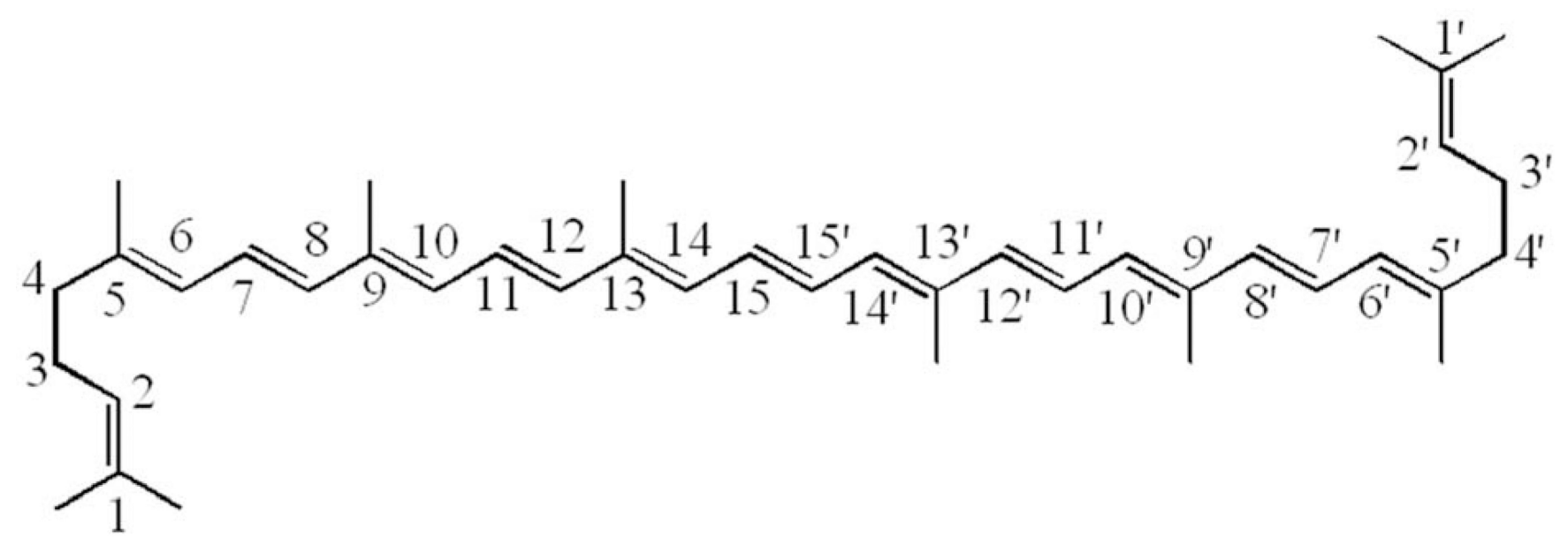

Figure 1.

Structure of all trans-lycopene. The number represents the carbon number in hydrocarbon chain. 


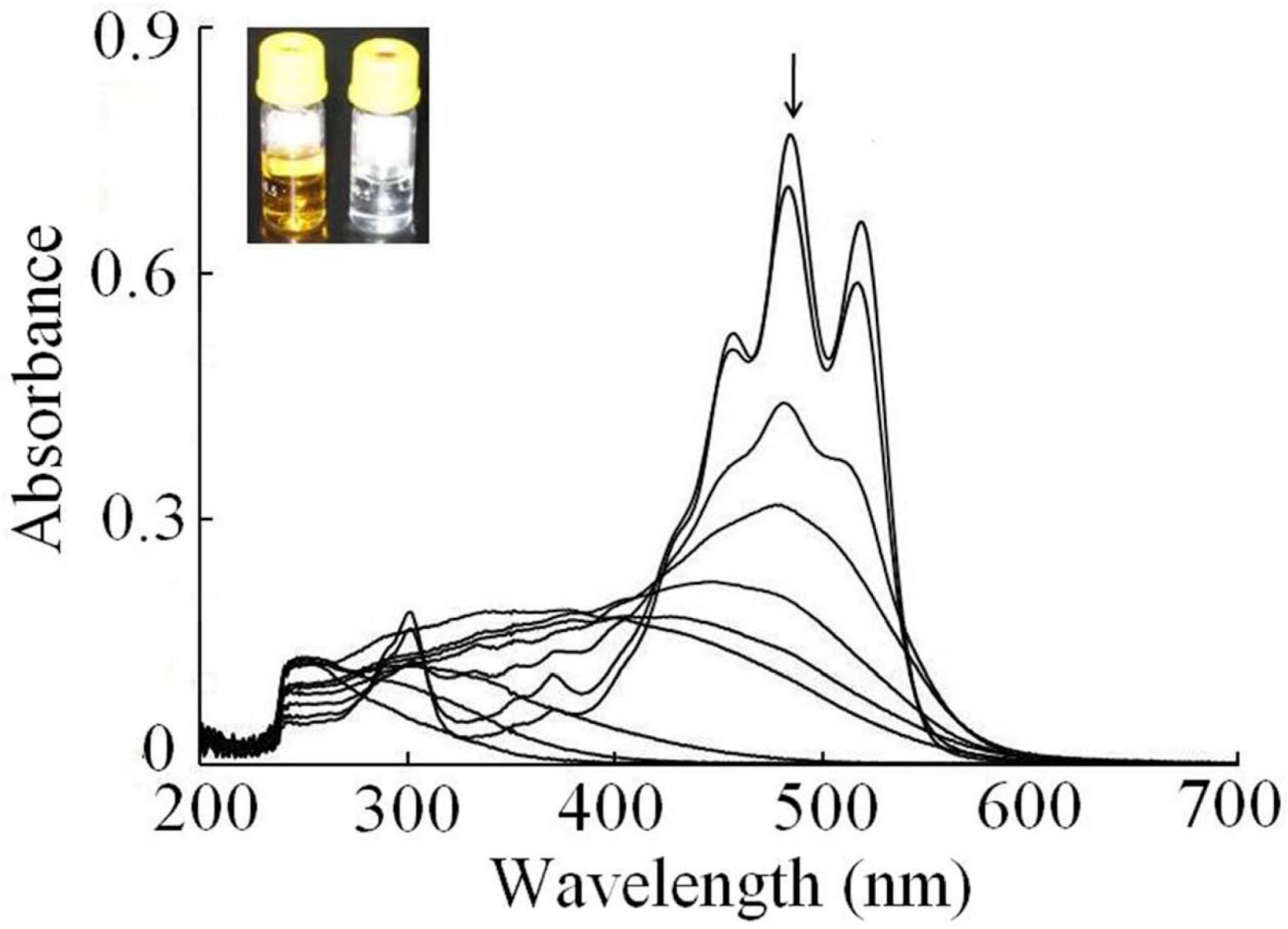

Figure 2.

Lycopene spectral changes as a function of $\mathrm{HOCl}$ concentration. Absorbance spectra of lycopene alone (top most spectra) and after reaction with 50, 125, 250, 500, 750, 1250, 1875,2500 and $3750 \mu \mathrm{M} \mathrm{HOCl}$, respectively (from top to bottom). The arrows show the direction of the absorbance decrease as a function of increasing $\mathrm{HOCl}$ ratio. The inset shows the color change of lycopene solution $(50 \mu \mathrm{M})$ when reacted with $3750 \mu \mathrm{M}$ of $\mathrm{HOCl}$. 
A
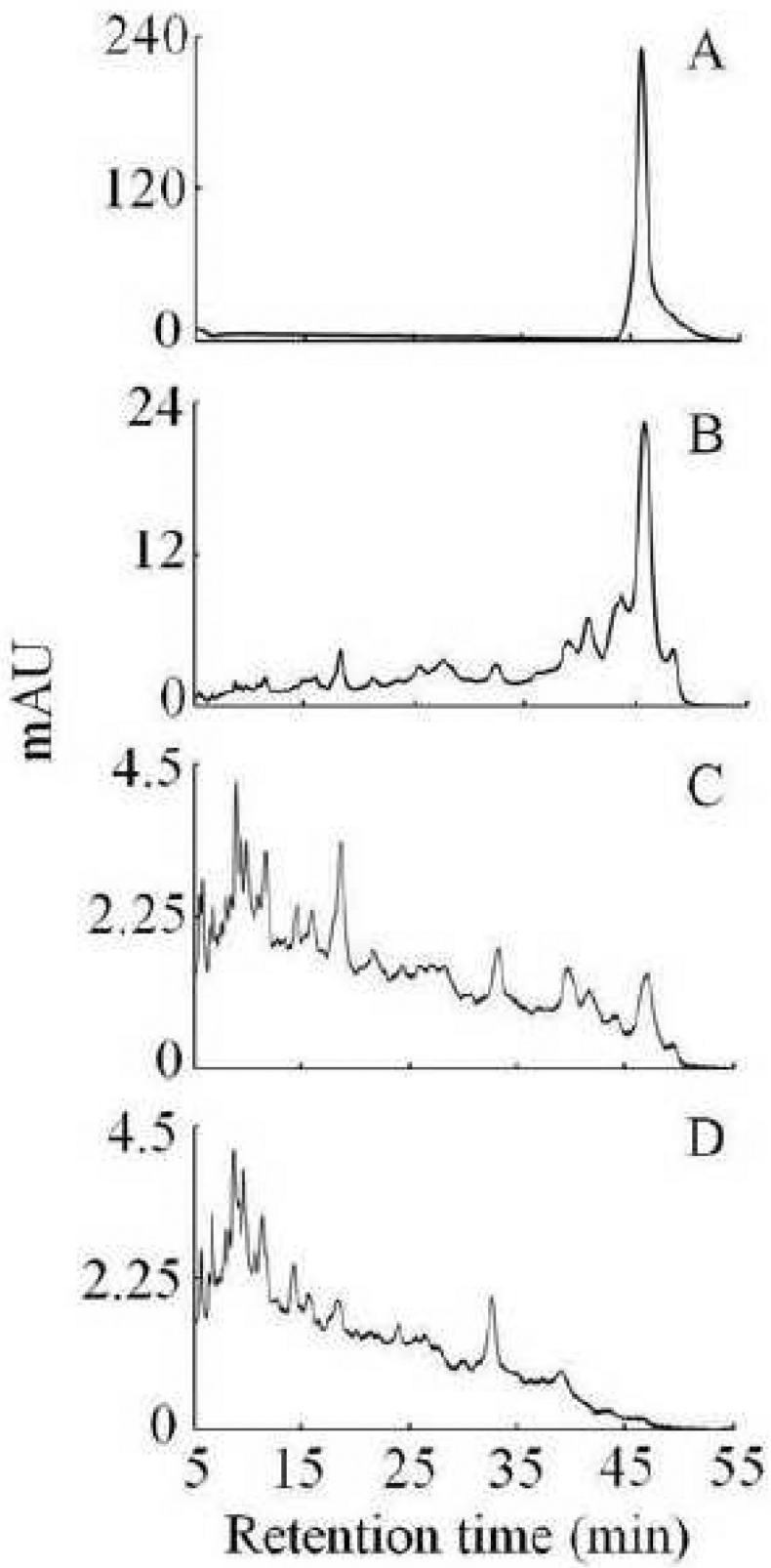

Free Radic Biol Med. Author manuscript; available in PMC 2012 August 10. 
B

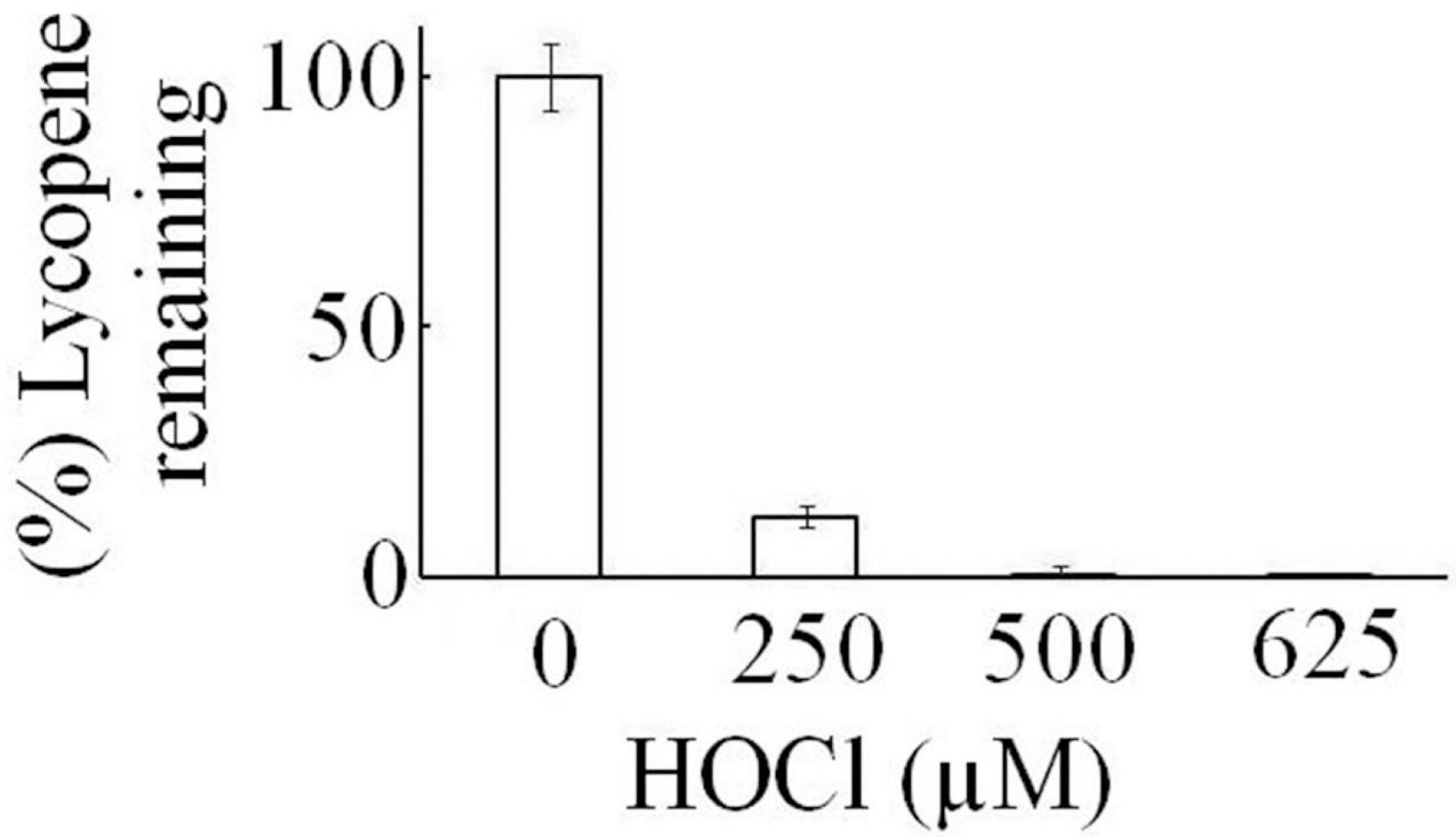

Figure 3.

A: HPLC analysis of the $\mathrm{HOCl}$ induced lycopene oxidation products. The figure shows the chromatograms obtained at $450 \mathrm{~nm}$, when lycopene $(50 \mu \mathrm{M})$ was reacted with different concentrations of HOCl. Panel A: $0 \mu \mathrm{M}$, B: $250 \mu \mathrm{M}, \mathrm{C}: 500 \mu \mathrm{M}$ and D: $625 \mu \mathrm{M} \mathrm{HOCl}$ respectively. The chromatograms are the representative set from three independent experiments.

B: Percent of lycopene remaining after reaction with different concentrations of $\mathrm{HOCl} .50$ $\mu \mathrm{M}$ of lycopene was reacted with different concentrations of $\mathrm{HOCl}(0,250,500,625 \mu \mathrm{M}$ respectively) and after HPLC analysis (for details see Materials and Methods section) the area under the curve for lycopene signal was integrated. The above result is the mean of three independent experiments and the error bars represent the Standard Error of Measurement. 


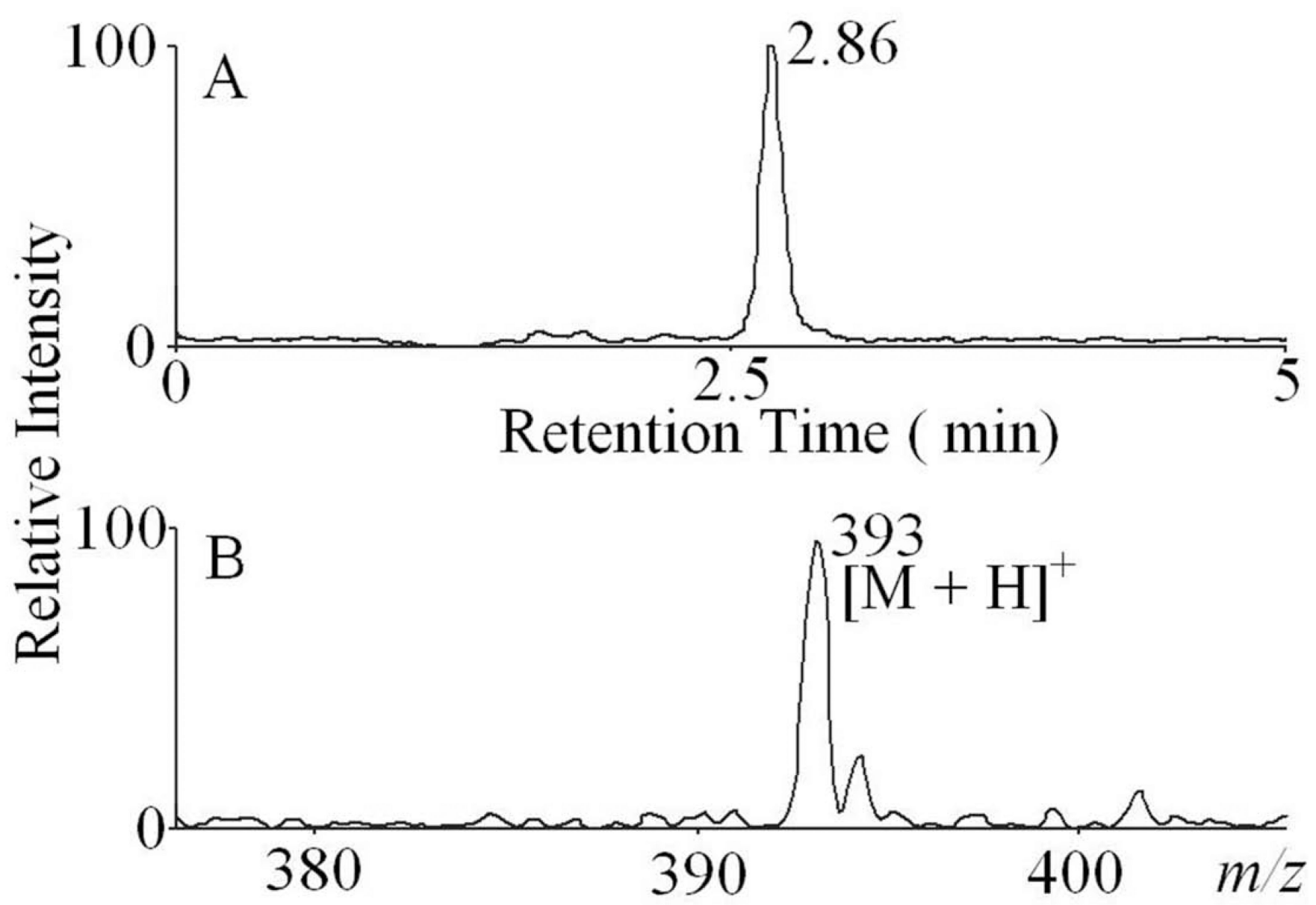

Figure 4.

Liquid Chromatography atmospheric pressure chemical ionization mass spectrometry (positive mode) of reaction of lycopene with $\mathrm{HOCl}$ (lycopene:oxidant ratio 1:5). The reaction mixture was separated by reverse phase HPLC and subjected to APCI/MS as described in Materials and Methods. The major reaction product produced an intense peak at $2.86 \mathrm{~min}$. Examination of the MS spectrum revealed that the $[\mathrm{M}+\mathrm{H}]^{+}$ion had a $\mathrm{m} / \mathrm{z} 393$. The extracted ion chromatogram (Panel A) and the MS spectrum of this peak (Panel B) are depicted. 


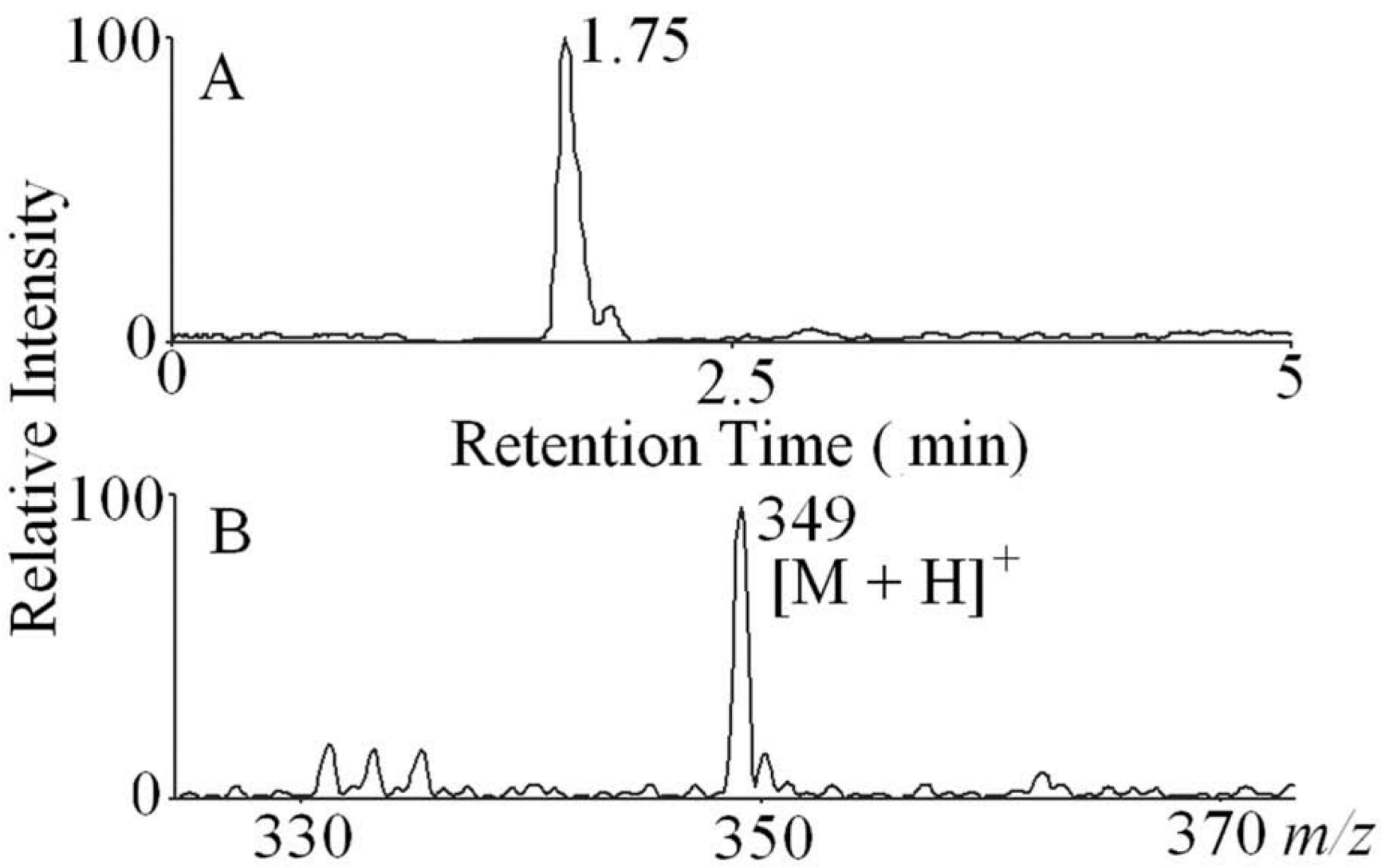

Figure 5.

Liquid Chromatography atmospheric pressure chemical ionization mass spectrometry (positive mode) of reaction of lycopene with $\mathrm{HOCl}$ (lycopene:oxidant ratio 1:5). The reaction mixture was separated by reverse phase HPLC and subjected to APCI/MS as described in Methods. The second major reaction product produced an intense peak at 1.75 min. Examination of the MS spectrum revealed that the $[\mathrm{M}+\mathrm{H}]^{+}$ion had a $\mathrm{m} / \mathrm{z} 349$. The extracted ion chromatogram (Panel A) and the MS spectrum of this peak (Panel B) are depicted. 


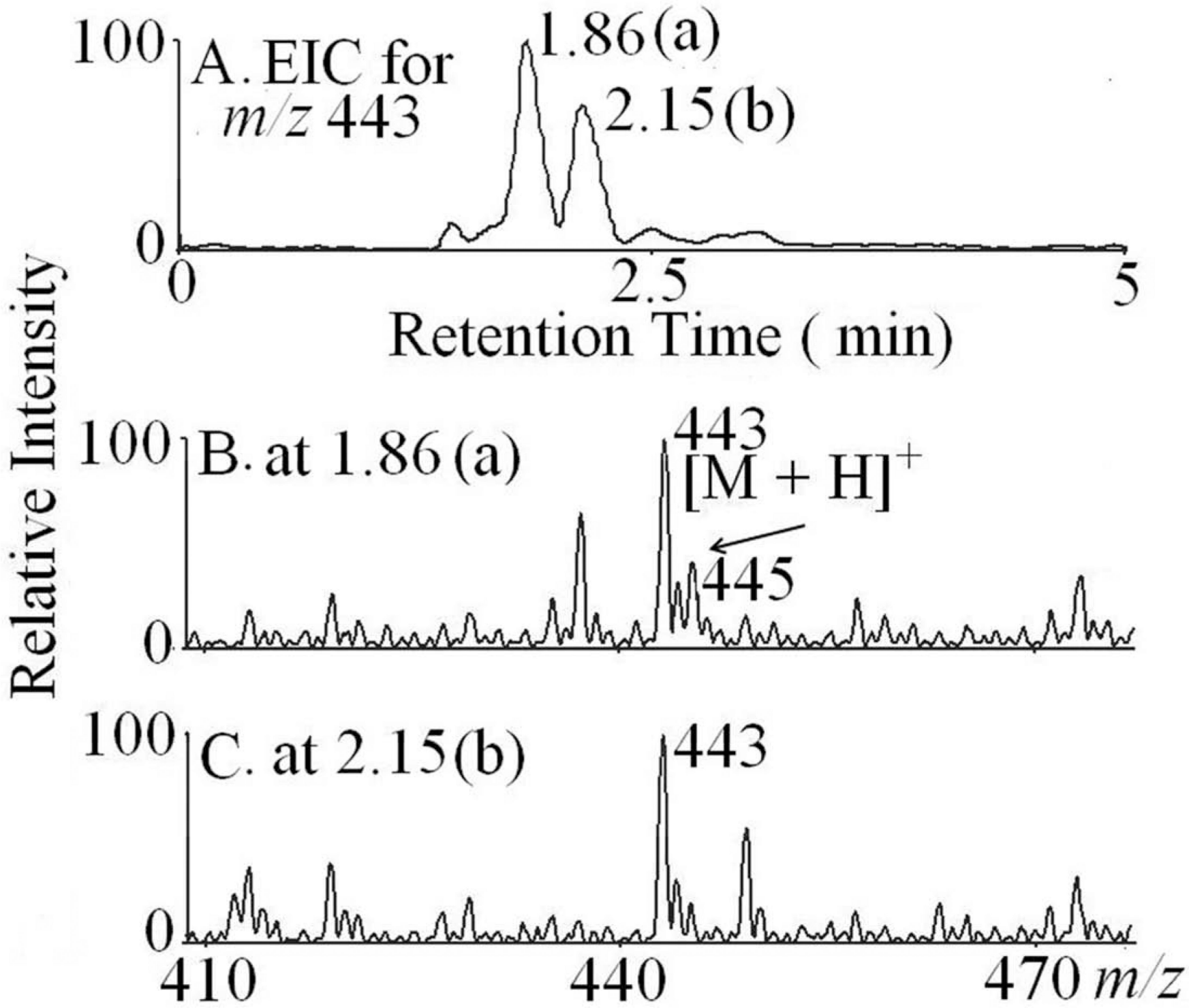

Figure 6.

Novel reaction products of lycopene with $\mathrm{HOCl}$ (lycopene:oxidant ratio 1:20). The reaction mixture was separated by reverse phase HPLC and subjected to APCI/MS as described in Methods. Two new metabolites were detected at retention times $1.86 \mathrm{~min}$ and $2.14 \mathrm{~min}$. Examination of the MS spectrum revealed that the $[\mathrm{M}+\mathrm{H}]^{+}$ion had a $\mathrm{m} / \mathrm{z} 443$. The extracted ion chromatogram is shown in Panel A. The MS spectrum of the peak at 1.86 min (Panel B) and 2.14 min (Panel C) are depicted. Note presence of one chlorine atom as the ion intensity of $[\mathrm{M}+\mathrm{H}+2]^{+}$ion is approximately $40 \%$ of $[\mathrm{M}+\mathrm{H}]^{+}$indicating chlorine isotope pattern in Panel B. In contrast, the isotopic pattern of $m / z 443$ from the second peak has no intense $[\mathrm{M}+\mathrm{H}+2]^{+}$ion (Panel $\mathrm{C}$ ) indicating that this product is not chlorinated. 
<smiles></smiles><smiles>CC=CC=CC1CC(Cl)CC1C=CC=CC1CC1[Ge](C)O</smiles><smiles>C=C/C=C/C1(Cl)[CH]OCCC1</smiles>
Chloronium ion

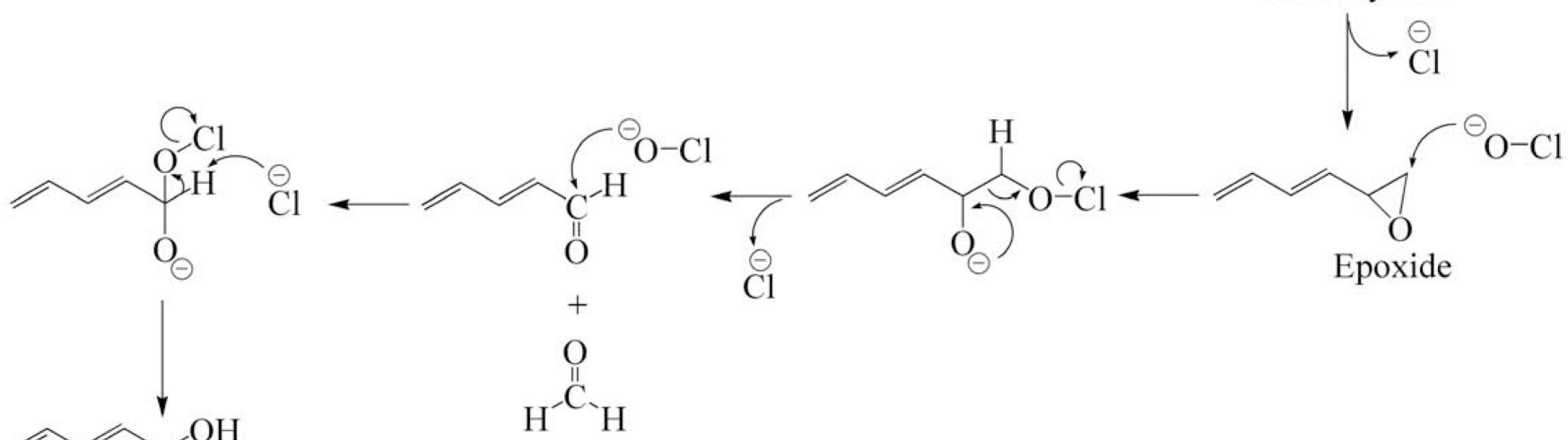
$\mathrm{O}$

Aldehyde

Carboxylic Acid

Figure 7.

Proposed chemical mechanism showing the stepwise oxidation of lycopene by $\mathrm{HOCl}$. 


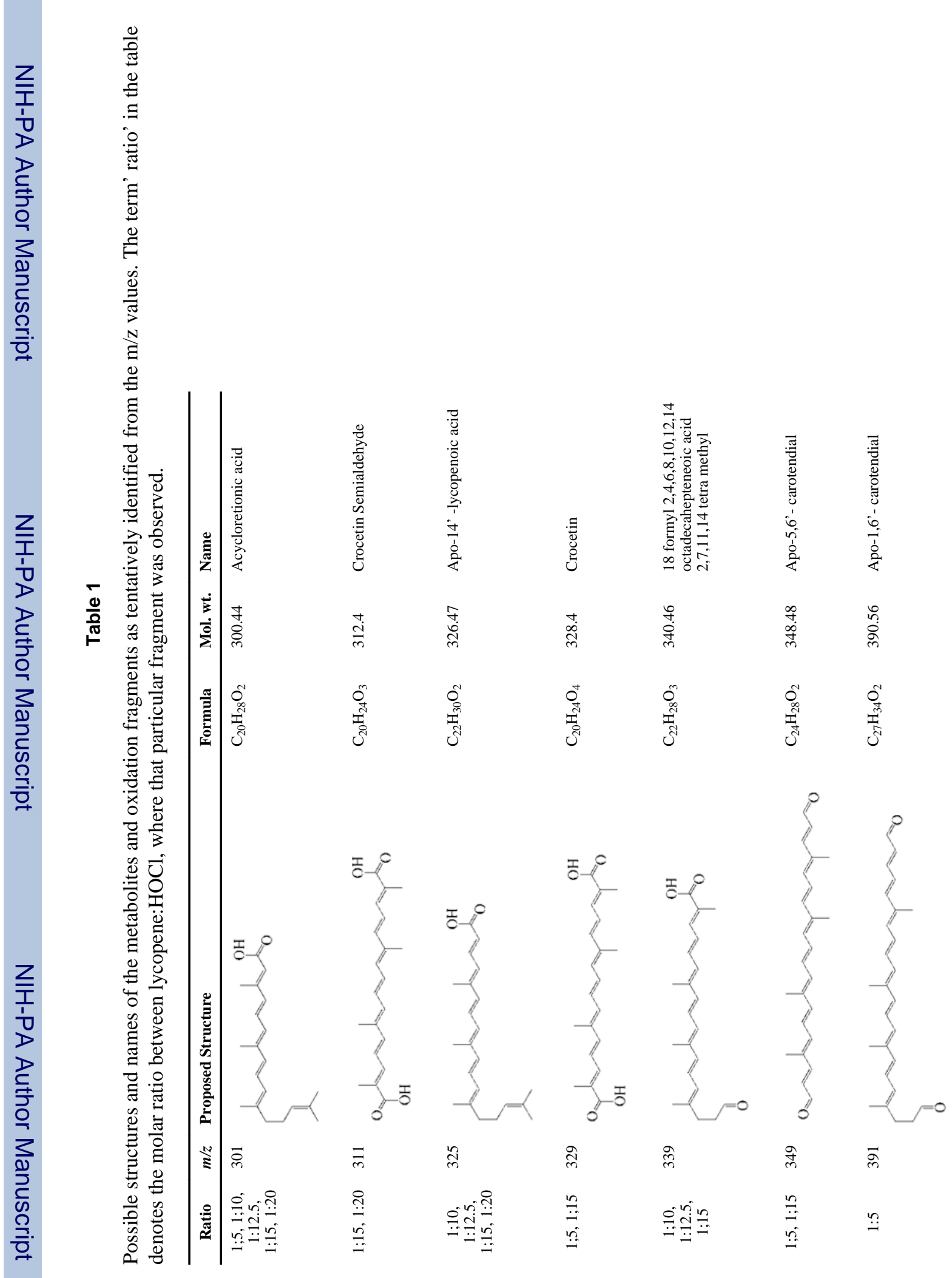




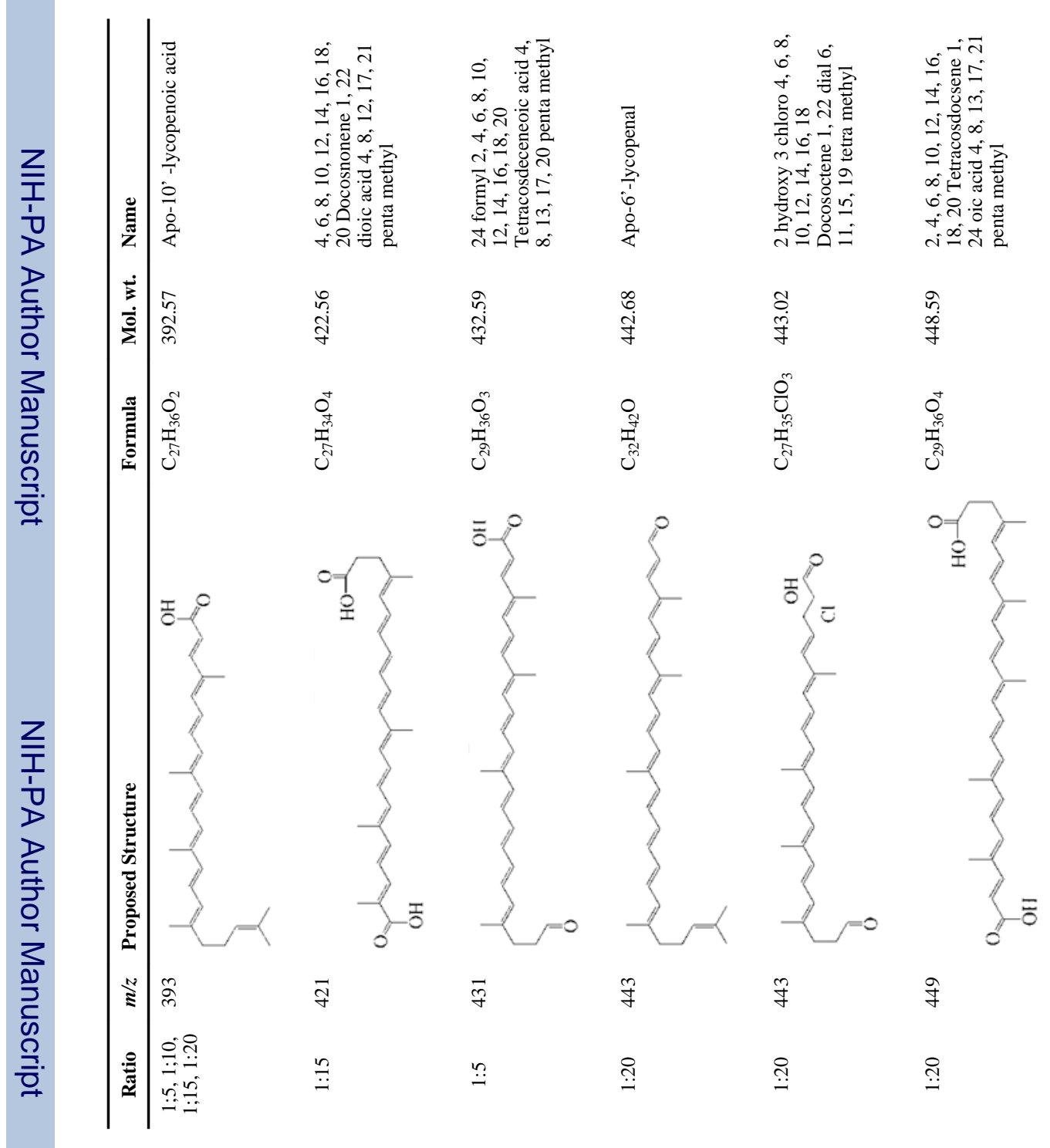

